\title{
ANALYTICAL SUPPORT OF THE MANAGEMENT ACCOUNTING SYSTEM IN AN UNSTABLE ECONOMY CONDITIONS
}

\author{
DZOBELOVA Batrazovna Valentina ${ }^{1}$, DOVTAEV Sayd-Ali Shakhidovich ${ }^{2}$, KUZINA \\ Anna Fedorovna ${ }^{3}$, SHADIEVA Movlatkhan Yusupovna ${ }^{4}$, \\ ELGAITAROVA Nargiz Takhirovna ${ }^{5}$
}

${ }^{I}$ North-Ossetian State University named after K.L. Khetagurova (RUSSIA)

${ }^{2}$ Department of Enterprise Economics, Chechen State University (RUSSIA)

${ }^{3}$ FSBEI HE "Kuban State Agrarian University named after Trubilin" (RUSSIA)

${ }^{4}$ Ingush State University (RUSSIA)

${ }^{5}$ North-Caucasian State Academy (RUSSIA)

\begin{abstract}
The globalization of the modern economic system, the scarce nature of the resources used, the depressive and stagnant nature of the current processes, the increasing complexity of the geopolitical situation and the deterioration of the environmental situation, etc. predetermine a serious transformation of the functions of accounting services and the role of accounting in the modern management system.

In these conditions, the need to study the impact of environmental factors on the nature of the enterprise activity and the mechanism for the development and adoption of managerial decisions are especially relevant. It is indisputable that the accounting organization system in a crisis situation should be different from its management in a sustainable development environment; this determines the need to improve managerial accounting methodology in conditions of unpredictability and instability of the external environment.

An analysis of the specialized literature suggests that there are insufficient studies of many aspects concerning the methodological content of the anti-crisis model of managerial accounting, the construction of its categorical apparatus, and the provision of a managerial accounting model in crisis processes in the economy, etc., which predetermined the choice of the topic of our study.
\end{abstract}

Keywords: economic crises, business entities, anti-crisis management accounting, analysis, information support

JEL: M41

UDC: 657.422

005.332:338.12

COBISS.SR-ID 28657417

\section{Introduction}

A characteristic feature of the processes in reforming the accounting system in the Russian Federation is its focus on rapprochement with generally accepted international standards with the emphasis on financial, tax and management reporting. Among the most pressing problems with regard to the development of the conceptual and applied foundations of the current methodology for management accounting in Russian business structures, we want to highlight 
the transformation of the methodology and objects for management accounting in an unstable economy.

When speaking about the crisis-functional relationship between management accounting and other sciences, it should be noted the growing contrast of objects, functions, techniques and methods of management accounting with the corresponding components of control, management, planning, etc. in the context of strategic and operational elements. This situation causes interdisciplinary disunity of management accounting and management accompanied by organizational and infrastructural underdevelopment, and lack of prognostic orientation.

As a rule, the subject matter of most of the works developed by Russian researchers is limited and mainly is focused on certain issues of cost accounting and calculating the actual cost of production. At the same time, many aspects of information support in innovative areas in management are at best considered but fragmentarily. In these conditions, the problem of using KPI technologies, compiling integrated reporting, developing a balanced scorecard from financial and non-financial indicators, etc., remain completely unexplored. Apparently, also for this reason Russian companies operating in world markets are very often faced with the situation when their reporting does not meet the information needs of users due to their inadequate analyticity and relevance.

The high level of discussion nature of various approaches and interpretations regarding the issues under consideration, forming the conceptual design framework of the management accounting, has shaped the focus of our study.

\section{Research methodology}

The basic principles of the institutionalism theory, managerialsystems, including cyclical development, crisis management, managerial accounting, and economic analysis became the theoretical base for the study.

The general scientific methods of cognition, such as system analysis, induction, deduction, comparison, formalization, etc., wereits methodological basis.

The regulatory framework of the Russian Federation in the field of accounting, IFRS, the works of domestic and foreign scientists, etc., served as an information base.

\section{Research results}

Globalization processes in the world economy objectively imply the development of modern tools of scientific, methodological and practical support for the sustainable growth of economic systems, which, undoubtedly, puts them among the most significant tasks in the state power system and in the scientific community. In the today's conditions of increasing competition, economic systems have become more nonequilibrium, which is associated with additional research in the field of monitoring and controlling the economic processes of the exogenous and endogenous environment, affecting the development sustainability of both individual enterprises and socio-ecological and economic systems in general.

A feature of the modern system of accounting and analytical support is its focus on accounting and analysis of internal information. It is clear that in such conditions almost all external information (independent of the activities of enterprises) falls outside the scope of mandatory accounting, which actualizes the unpreparedness of business entities for crisis phenomena. $[1,4,8]$

All this requires that the analysis of the environmentalsituation in the macroeconomic instability conditions become an everyday component of management accounting. It seems to us that this also requires the use of special principles and methods of constructing information for the development and adoption of managerial decisions, different from those that are 
applied in conditions of sustainable development. In today's realities, it is no longer impossible not to see that constantly changing economic circumstances can directly affect accounting and the practice of preparing financial statements. It seems to us that accounting cannot be seen as a dogma, as something forever established, because it is constantly influencedby a constantly changing environment.

It should also be noted that, as a rule, the effectiveness of management decisions made in practice depends on how much an accountant-analyst was able to consider the individual characteristics of the enterprise. This provision suggests that the constant use of only one unified approach in the implementation of accounting and analytical actions is not always appropriate and, moreover, can often lead to the adoption of ineffective management decisions. We proceed from the fact that an individual (creative) approach consists in the ability to the fullest extent consider the factors that shape the special aspects of activity of an enterprise.

Researchers note that the management accounting methodology is more dependent on the stage of the life cycle, which involves the use of a wide range of tools to implement the enterprise's strategic plan at the appropriate development stage [12].

Our analysis of the institutional evolutionary theory allowed us to identify environmental factors that influence the algorithm for the development and adoption of effective management decisions and to justify the mechanism for an adequate response to external market and macroeconomic triggers. In this format, the life cycle theory allows to a greater extent to consider the features of the strategic management accounting system.

The life cycle of an enterprise depends on its balance with the financial cycle, on the ability to influence it, and, thereby, steadily and proportionally develop economic systems at the micro level. In these conditions, the management accounting system must be directed to leveling internal contradictions that have the nature of organizational properties, as well as emerging conflicts with external factors when an enterprise moves to the next stage. $[15,17]$

To solve the complex of strategic management tasks, portfolio analysis methods, including such as the Boston Consultancy Group matrix, life cycle matrix (ADL), etc. are actively used

A characteristic feature and commonality of these models is the combination of some systemevolvement parameters of different levels such as a company, product, or even a particular sector of the economy.

In our opinion, the strategic goal of any enterprise in the face of increasing competition is the implementation of such a business model that can enable the generation of sufficient added value with any environmental changes. This situation implies the need for structuring the properties of the accounting and analytical system with all kinds of combinations of stages of the enterprise life cycle.

Being a direct factor in the macroenvironment, any stage of the life cycle itself actively forms management accounting models and affects the configuration of the methods used that are generally accepted for the accounting direction under study. In modern economic realities, stable economic growth can only be achieved through effective management of business structures at the micro level, subject to prompt and accurate management decisions. All this is associated with the need to search for effective tools to increase the relevance of the generated information base.

Let us turn to the consideration of macro environment factors affecting the configuration of the used management accounting tools. In recent years, the tendency on transformation of the subject of financial accounting comes into more and more sharp focus. Moreover, if in the past it was determined by the composition of assets and liabilities in the balance sheet, at the present stage the market economy itself determines the subject of accountingunder the influence of cyclical and evolutionary processes. Globalization and structural changes at the 
micro level are accompanied by changes in the tools of operational and strategic management at the level of individual business entities. [2, 16, 18]

Traditionally, accounting and analytical work has always been aimed at reflecting only the facts of economic life. At the same time, a complex of macroeconomic factors that are exogenous with respect to a business entity, which is very important for the financial situation of the enterprise, was ignored when making management decisions. It seems to us that this fact cannot be explained by the mere conservatism of the accounting methodology, because macroeconomic processes unequally affect various sectors of the economy, which makes it extremely difficult to monitor and control the financial situation of the enterprise. All this emphasizes once again thata special consideration of the factor of the economy crisis state is relevant.

The study of the essence of the economic crisis impact on the management system allows us to note a number of contradictions in the system of accounting and analytical support.

First of all, it concerns the attitude to costs. Under current conditions, there is a mismatch between the policy of the need to reduce costs due to a lack of own funds and the policy of the need to increase costs to intensify the business activity of enterprises.

Further, the need to establish anti-crisis funds while escalating the financing of current operations is controversial.

It is also possible to note certain contradictions in the choice of priorities in the methods of generating information, in the style and priorities in management, in the stable tendency of the faster growth of financial and economic technologies over accounting and analytical technologies; those factors negatively affect the prognostic potential of the generated information base and thereby strengthen unpredictability in identifying threats and risks of manifestation of economic crises at both micro and macro levels. [3, 11, 14]

To eliminate the above and other contradictions, we need in new effective methodological approaches to the development of relevant data in order to provide information-analytical support for making managerial decisions. Modern accounting methodology is characterized by increasing integration with tools for generating relevant information in systems such as financial management, crisis management, controlling, marketing, economic and mathematical modeling, statistical and econometric analysis, etc. Undoubtedly, all this form an additional synergetic effect in the system strategic management of business structures and thereby expands the subject and functions of management accounting.

In these conditions, in our opinion, the study of the anti-crisis aspect of management accounting becomes even more relevant. Indeed, in conditions of increasing uncertainty and instability of macroeconomic processes, which impedes the stable development of enterprises, it is necessary, first of all, to develop the functions of warning, which anticipate crisis phenomena in the management accounting system.

Experts note that economic crises violate generally accepted and well-established approaches to making managerial decisions through a complex impact on the information support system itself. [7, 10] As an example of such a transformation, we can consider a change in attitude to assets as an economic category. So, if in modern accounting, the composition, methods of valuation and recognition of assets are almost the same as they were fifty years ago, then from the perspective of investments, a number of highly liquid assets influenced by global financial crises $(2008,2014)$ became less liquid (these include, including, real estate, securities, etc.) in today's realities.

It seems to us that all this should affect the system of accounting and analytical support for the activities of enterprises. So, for example, it is necessary to modify the management accounting system to achieve the proper management of assets, liabilities, income and expenses in the new economic conditions. In addition, it should be noted that in the context under review, many objects of financial accounting are moving into the sphere of 
management accounting, direct penetration of the constituent methods of financial and management accounting is performed out.

All this allows us to argue that at the present stage the accounting methodology is subject to pressure from macro environment factors, which, to a significant extent, modifies the tools of management accounting.

Indeed, the development of the post-industrial economy is accompanied by evolutionary processes not only in the system of ongoing business processes, but also by the need to adapt the management accounting technologies used to the specifics and characteristics of crisis phenomena in the economy.

All this suggests that the modern methodology of managerial accounting must be adapted to the functioning of enterprises in the face of increasing competition, quite often accompanied by a fall in traditional markets. The successful conduct of modern business requires learning to diagnose the environment, anticipate its depressive development, which will allow timely identification and subsequent leveling of negative trends for the efficient operation of the enterprise.

An analysis of the works of Russian scientists suggests that almost the majority of the developments are devoted to diagnosing the financial situation of enterprises and, at the same time, the whole set of recommendations for the anti-crisis nature does not go beyond an enterprise.

In fact, it seems to us that the deteriorating financial situation of an economic entity, in our case, is not the cause of the crisis situation, but its consequence, because crisis processes affect not only the finances of an enterprise, but also other areas of its activity, including accounting tools and the order of production and financial activities of an economic entity.

In the conditions of increasing competition and the instability of economic conditions, the system of accounting and analytical support for an enterprise should have some flexibility and adaptability to ensure the use of effective management tools for implementing the strategic plan and operational tasks of the enterprise.

Among these tools, there can be noted a balanced scorecard (developers - D. Norton and R. Kaplan). [6] Its use allows managers to have a balanced view of the main production and financial activity indicators, through which it is possible to reliably evaluate various aspects of the functioning of an enterprise at the same time. Indeed, a set of various financial indicators allows us to see the results of the implemented measures and managerial decisions, but financial indicators alone do not allow us to evaluate the future economic values of an enterprise. Hence, it must be assumed that the process of strategic management of an enterprise also requires the development of a certain array of non-financial indicators, which, together with financial indicators, objectively reflect the actual financial, economic, social and market situation of the enterprise and its ability to implement a given strategy. [13]

Other models of management accounting and strategic management are also very popular abroad, including economic added value model, triple reporting system, strategic position matrix and action assessment, etc.

Among Russian researchers in this area, we may note G. B. Kleiner; he considers the fifteen functions of an enterprise, including anti-crisis stabilizing function. [2]

In general, we must admit that in times of crisis, an analyst should also pay special attention to the state of the external environment, because at the present stage, the financial situation of Russian enterprises to a large extent depends on the influence of external factors.

\section{Conclusions and proposals}

In the course of the study, we analyzed various approaches of the conceptual-theoretical and organizational-methodological substantiation of the management accounting system in an 
unstable economy, which allowed us to identify a wide variety of factors which are the basis of the genesis of economic development, and at the present stage have a direct impact on the methodological content of management accounting.

It is proved that the economy cyclical development factor is one of the key ones when considering approaches to the formation of the management accounting concept. This situation indicates the objective need to change user requests for relevant information concerning the development and adoption of effective management decisions in a nondeterministic environment; it is the evidence that economic crises in the economy significantly affect, among others, the improvement of the management accounting methodology.

Using a systematic approach allows us to modify the anti-crisis model of managerial accounting, and also to level out the resulting disorder in the construction of elements of the managerial accounting theory, and thereby to develop effective tools for creating relevant information to work out effective management decisions in the today'sconditions of unstable economy.

\section{REFERENCES}

[1] Adizes I. How to overcome management crises. Diagnostics and solution of managerial problems. St. Petersburg: Stockholm School of Economics, 2007. P. 294.

[2] Berdnikov V.V. Analytical tools for developing and monitoring the effectiveness of business models // Audit and financial analysis. 2013. No. 3. Pp. 283-294.

[3] Bulgakova S.V. Prerequisites, conditions for the emergence and periodization of the development of management accounting // Bulletin of Voronezh State University. Series: Economics and Management. 2005. No. 2. Pp. 198-204.

[4] Vakhrushina M.A. Problems and prospects of development of Russian management accounting // International Accounting. 2014. No. 33. Pp. 12-23.

[5] Gerasimov V.O., Sharafutdinov R.I., Kolmakov V.V., Erzinkyan E.A., Adamenko A.A., Vasileva A.G. Control in the human capital management system in the strategy of innovative development of a region. Entrepreneurship and Sustainability lssues. 2019. T. 7. № 2. Pp. 1074-1088.

[6] Kaplan R. Balanced scorecard. From strategy to action / R. Kaplan, D. Norton. Translation from English. M.: Olympus Business. 2003. P. 320.

[7] Kaspina R.G. Application of a process-oriented approach in management accounting to the formation of a business model of an organization // International Accounting. 2013. No. 39. Pp. 2-8.

[8] Kogdenko V.G. Features of the financial policies of companies in a crisis // Economic analysis: theory and practice. 2015 . No. 15. pp. 2-14.

[9] Kolupaev A.A., Voronkova O.Yu., Vakhrushev I.B., Adamenko A.A., Solodkin V.S., Alekhina N.A. Corporate identity of lodging establishment as a factor of increasing tourism activity in the region. Proceedings of the $33^{\text {rd }}$ International Business Information Management Association Conference, IBIMA, 2019: Education Excellence and Innovation Management through Vision 2020. Pp. 7948-7956.

[10] Legenchuk S.F. World trends in the development of accounting in a post-industrial economy // International Accounting. 2011. No. 8. Pp. 56-62.

[11] Ovsyannikov S.V. Formation of an anti-crisis strategy based on factors of the organization's life cycle // Bulletin of the Voronezh State Agrarian University. 2012. 32. Pp. 274-279.

[12] Rumyantseva E.E. New Economic Encyclopedia. $4^{\text {th }}$ edition. M.: Publishing House Forum: INFRA-M, 2012. P. 256.

[13] Fomchenkova L.V. Transformation of the strategic analysis tasks in the context of organizational development // International Research Journal. 2016. № 4-1. Pp. 127-129.

[14] Dzobelova, V., Olisaeva, A. (2018) Analysis of innovative development of the NCFD regions in Russia. IDIMT 2018: Strategic Modeling in Management, Economy and Society $-26^{\text {th }}$ Interdisciplinary Information Management Talks, pp. 473-479.

[15] Misakov V.S., Misakov A.V., Tsurova L.A., AdzhievaA.Yu., Eskiev M.A. Ways of improving the economic mechanism for the social development of rural settlements of mountainous areas//International Journal of Advanced Biotechnology and Research. 2017. V. 8., № 4. Pp. 964-972. 
[16] Misakov V.S., Tsurova L.A., Yandarbieva L.A., ThamadokovaI.Kh., Goigova M.G. Certification of regional economic complex as a highly effective tool for analysis and diagnostics of its development // Amazonia Investiga. 2019. V. 8., № 20. Pp. 451-458.

[17] MisakovV.S., KhamzatovV.A., TemrokovaA.Kh., MisakovA.V., DikarevaI.A. Strategic management of innovative agro-industrial projects // Amazonia Investiga. 2018. V. 7., № 14. Pp. 16-23.

[18] Ugurchiev O.B., DovtaevS.A.Sh., Misakov V.S., Misakov A.V., Temmoeva Z.I., Gyatov A.V. Transition mechanism development to the sustainable balanced development of depressive territories // The Turkish Online Journal of Design Art and Communication. 2018. V. 8. № S-MRCHSPCL. Pp. 248-253.

\section{Article history:}

Received 13 April 2020

Accepted 25 August 2020 